\title{
ДИНАМІЧНЕ СПОСТЕРЕЖЕННЯ ЗА ДОРОСЛИМИ ПАЦІЄНТАМИ 3 ЮВЕНІЛЬНИМ РЕВМАТОїДНИМ АРТРИТОМ
}

\section{Національний медичний університет імені О. О. Богомольця, Київ}

РЕЗЮМЕ. Протягом останніх років у лікуванні ювенільного ревматоїдного артириту (ЮРА) відбувся суттєвий прогрес, пов'язаний із розробленням інноваційних лікарських засобів, хоча доступність для українських пацієнтів обмежена через високу ціну та відсутність достатнього державного забезпечення.

Мета роботи - провести обстеження молодих дорослих пацієнтів з ЮРА на момент звернення до дорослого ревматолога та через рік спостереження з оцінкою динаміки клінічних, лабораторних показників, психологічного стану, стану мінеральної щільності кісткової тканини та проведеного лікування.

Матеріал і методи. У дослідження включено 168 пацієнтів з ЮРА, що досягли 18-річного віку, які були обстежені на базі Олександрівської міської клінічної лікарні, М. Київ з оцінкою клініко-лабораторних паказників активності захворювання, якості життя (ЯЖ) за SF-36, алекситимії за TAS, рівня депресії за PHQ-9, стану мінеральної щільності кісткової тканини та отриманого лікування.

Результати. При динамічному спостереженні за дорослими пацієнтами з ЮРА протягом 1 року на фоні терапії згідно з Уніфікованим клінічним протоколом медичної допомоги хворим з ЮРА виявлено зменшення тривалості ранкової скутості $(p<0,05)$, покращення суглобового синдрому, зменшення артриту кистей $(p<0,05)$, артриту більше трьох суглобів ( $<<0,05)$, симетричного артриту $(p<0,05)$, ентезитів $(p<0,05), 6$ бол в хре6ті $(p<0,05)$, що відо6разилося в зниженні $(p<0,05)$ ступеня функціональної недостатності суглобів та відсутності рентгенологічного прогресування, не збільшилася потреба в протезуванні суглобів, не виявлено динамічних змін системних проявів, наявності увеїту та сакроілеїту. Виявлено відсутність позитивної динаміки лабораторних показників активності ЮРА в дорослому віці за DAS28 та JADAS, ШОЕ, СРБ, хоча $\epsilon$ тенденція до їх зменшення. У пацієнтів з ЮРА залишається активність захворювання через 1 рік спостереження в дорослому віці. За рік спостереження виявлено збільшення рівня вітаміну 25-(OH) (p<0,05), хоча він все ще не нормалізувався. Встановлено, що як на момент первинного огляду, так і після спостереження протягом 1 року МЩКТ в різних ділянках скелета та Z- і Т-показники відповідних ділянок були достовірно нижчими, порівняно з групою контролю. Однак, при оцінці МщКТ в різних відділах скелета та Z- і T-показників відповідних ділянок не виявлено їх динамічних змін протягом року спостереження. Через 1 рік спостереження не виявлено відмінностей ні за ЯЖ та її шкалами, ні за рівнем алекситимії, ні за ступенем депресії. Хоча 4 \% пацієнтів з ЮРА після 1 року спостереження в дорослому віці мали від легкої «субклінічної» до середнього ступеня тяжкості депресію, тоді як на момент первинного огляду дорослим ревматологом ознаки депресії різного ступеня спостерігали у $61,1 \%$ пацієнтів.

Висновки. У дорослих пацієнтів з ЮРА, що перебували під спостереженням протягом 1 року, відмічена стабілізація як клінічного, так і психологічного стану. Через 1 рік спостереження виявлено зменшення тривалості ранкової скутості та покращення суглобового синдрому, що відобразилося в зниженні ступеня функціональної недостатності суглобів та припиненні рентгенологічного прогресування, однак утримувалась висока лабораторна активність. При оцінці МщКТ у різних відділах скелета та Z- і Т-показників відповідних ділянок не виявлено її позитивних динамічних змін протягом року спостереження. Через 1 рік спостереження за дорослими пацієнтами з ЮРА не виявлено відмінностей в ЯЖ за її шкалами, алекситимії, та ступені депресії, що свідчить про необхідність корекції за участі відповідних спеціалістів. Встановлено, що 32 (19\%) пацієнти від дебюту захворювання до дорослого віку не приймали хворобомодифікуючих препаратів, та отримували терапію лише НПЗП та локально глюкокортикоїдами, 53 (31,5 \%) пацієнти приймали протягом всієї тривалості захворювання 1 хворобомодифікуючий препарат, 34 (20,2 \%) пацієнти отримували послідовно або паралельно 2 хворобомодифікуючих препарати, 11 (6,5 \%) пацієнтів отримували послідовно або паралельно 3 хворобомодифікуючих препарати, 19 (11,3 \%) пацієнтів отримували 1 хворобомодифікуючий препарат та 1 препарат ІБТ, 10 (6\%) пацієнтів отримували 2 хворобомодифікуючих препарати та 1 препарат ІБТ, 9 (5,4 \%) пацієнтів отримували більше 3 хворобомодифікуючих препаратів або більше 2 препаратів ІБТ.

КЛючОВІ СЛОВА: ювенільний ідіопатичний артрит; дорослий вік; якість життя; лікування.

Вступ. В останні роки увага ревматологічної спільноти України прикута до проблеми передачі до дорослої служби охорони здоров'я та подальшого спостереження і лікування пацієнтів з ювенільним ревматоїдним артритом (ЮРА) в дорослому віці. В 2016 році вперше була опублікована проблемна стаття за участі провідних дитячих та дорослих ревматологів України з пропозиціями щодо необхідності внесення змін та доповнень до Адаптованої клінічної настанови та Уніфікованого клінічного протоколу медичної допомоги дітям, хворим на ЮРА, з метою ширшого застосування провідних світових підходів до лікування цього захворювання та передачі пацієнтів із дитячого та підліткового віку в категорію дорослого населення [1]. Протягом останніх років у лікуванні 
Огляди літератури, оригінальні дослідження, погляд на проблему, ювілеї

ЮРА відбувся суттєвий прогрес, пов'язаний насамперед із впровадженням нових методів діагностики, терапії та розробленням інноваційних лікарських засобів. В Українському кризовому медіа-центрі 15.02.2018 р. відбувся круглий стіл за участі лікарів та громадських організацій «Лікування хворих на ювенільний ревматоїдний артрит: чи $є$ шанс у дітей після 18 років?» [2]. Оскільки у ряді випадків базова хворобомодифікуюча терапія $\epsilon$ неефективною і пацієнтам необхідна високовартісна терапія імунобіологічними препаратами (ІБТ), пацієнтські організації в Україні об'єднали зусилля та звернулися до Мінфіну з питанням про виділення коштів на лікування дорослих, хворих на ЮРА, оскільки державне забезпечення лікування дорослих з ЮРА $є$ недостатнім. Так, у м. Києві станом на січень 2018 р. зареєстровано 293 хворих на ЮРА дітей, з них 53 (19\%) дитини отримує ІБТ, метотрексат - 76 \% хворих. Загалом у 2009-2017 рр. ІБТ отримували 70 дітей, з них 43 - застосовували адалімума6, 23 - тоцилізума6 і 4 дитини - етанерцепт. За останній рік дитячі ревматологи передали до дорослої ревматологічної служби 24 хворих, серед них - 9 дітей, які перебувають на імунобіологічній терапії, 46 \% препаратів для імунобіологічної терапії закуплено за кошти місцевого бюджету м. Києва [2].

Характер віддалених наслідків ЮРА в дорослому віці залежить не лише від варіанту ЮРА, активності захворювання та ступеня втягнення в патологічний процес тих чи інших органів-мішеней, а й від проведеної терапії, її ефективності, дози та тривалості. Відомо, що найчастіше побічні ефекти розвиваються у хворих внаслідок тривалого прийому глюкокортикоїдів (ГК) та на тлі відсутності адекватної відповіді на базисні хворобомодифікуючі синтетичні або імунобіологічні препарати. Враховуючи актуальність проблеми ЮРА та зацікавленність нею не лише медиків, а й громадських організацій [2], ми поставили перед собою мету провести обстеження дорослих пацієнтів з ЮРА на момент звернення та через рік спостереження, з оцінкою динаміки клінічних, лабораторних показників, психологічного стану (в т.ч. якості життя та наявності депресивного стану різного ступеня вираженості), стану мінеральної щільності кісткової тканини та проведеного лікування.

Матеріал і методи дослідження. В дослідження включено 168 пацієнтів з ЮРА, що досягли 18-річного віку. В цю групу ввійшли пацієнти з різних регіонів України, яким встановлено діагноз ЮРА в період між 1984 та 2013 р. Критеріями включення були пацієнти з діагнозом ЮРА за класифікаційними критеріями міжнародної ліги асоціації ревматологів (International League of Associations for Rheumatology - ILAR) [3]. Усі пацієнти обстежені амбулаторно або стаціонарно на базі Олександрівської міської клінічної лікарні, м. Київ, у період між квітнем 2015 та березнем 2017 р., $з$ оцінкою тривалості захворювання, системних проявів, наявності увеїту, висипки, лихоманки, характеру суглобового синдрому, наявності ревматоїдного фактора (РФ), антитіл до циклічного цитрулінового пептиду (А-ЦЦП), антинуклеарного фактора (АНФ), HLA-B27, медикаментозного лікування на момент огляду та в анамнезі, в тому числі імунобіологічної терапії. Оцінку якості життя (ЯЖ) пацієнтів з ЮРА проводили з використанням опитувальника Short-Form-36 (SF-36). SF-36 - це багатоцільовий короткий медичний опитувальник з 36 питаннями [4, 5]. Ми використовували ліцензований доступ (Ліцензія QМ037587) для некомерційних академічних досліджень від управління наукових грантів та досліджень (OGSR), що надається компанією Optumlnsight Life Sciences, Inc. Ця версія включає нові загальні норми 2009 року для населення разом з загальними нормами населення 1998 року. Після оцінки яЖ, незалежно від їі результатів, усім пацієнтам з ЮРА, було роздано опитуальник Торонтської шкали алекситимії (TAS-20), за допомогою якого оцінювали рівень алекситимії. 3 розданих 118 анкет зворотну відповідь отримали від 108 пацієнтів (91,5 \%). Оцінку проводили за підрахунком кількості балів, а саме 62 і менше балів - трактувалося як норма, 63-73 бали - вважалося «групою ризику», 74 і більше балів - алекситимією. Для оцінки наявності та визначення ступеня тяжкості депресії використовували «Опитувальник пацієнта про стан здоров'я (Patient Health Questionnaire - PHQ-9)» шкала самооцінки депресії з дев'яти пунктів [6]. Крім того, проводили дослідження стану кісткової тканини на базі ДУ «нститут геронтології ім. Д. Ф. Чеботарьова НАМН України», Українського науково-медичного центру проблем остеопорозу методом двоенергетичної рентгенівської денситометрії (Prodigy, GE Lunar, Мадісон, США) 3 визначенням мінеральної щільності кісткової тканини (МЩКТ) на рівні всього скелета (ВС), поперекового відділу хребта L1-L4 (ПВX), шийки стегнової кістки (ШСК) та ультрадистального відділу кісток передпліччя (КП), а також Т-показник і Z-показник в зазначених ділянках скелета. За пацієнтами проводили динамічне спостереження, та, при необхідності, - корекцію терапії згідно з затвердженими клінічними протоколами [7], та через 1 рік після спостереження повторно оцінювали стан пацієнта. На повторний огляд через 1 рік прийшло 56 (33,3 \%) пацієнтів, що пов'язано з кількома факторами. По-перше, частина пацієнтів переїхала в інше місце проживання у зв'язку з поступленням до ВУЗів чи працевлаштуванням (34 пацієнти 20,2%). По-друге, 17 (10,1%) пацієнтів перейшли 
Огляди літератури, оригінальні дослідження, погляд на проблему, ювілеї

під спостереження в ДУ «Національний науковий центр «Інститут кардіології імені М. Д. Стражеска» НАМН України», Київ, у зв'язку з можливістю отримувати безкоштовну ІБТ. Також 39 \% не з'явилися на прийом з інших причин.

Статистичний аналіз проводили за допомогою загальноприйнятих методів описової статистики та методів порівняння вибірок (критерію Стьюдента для незв'язаних змінних, критерію Манна-Уїтні, критерію $\chi^{2}$ Пірсона). Для безперервних змінних дані представлені як середнє \pm стандартне відхилення (SD) у випадку Гаусівського розподілу та у вигляді квартилів, мінімуму та максимуму для ненормального розподілу. Для категорійних змінних розраховані абсолютні значення та відсотки. Статистично значимим вважали значення імовірності $p<0,05$. При аналізі використовували пакети програм «Statistica 6.0» Copyright StatSoft, Inc. 1984-2001.
Результати й обговорення. При динамічному спостереженні за дорослими пацієнтами з ЮРА протягом 1 року на фоні терапії згідно з Уніфікованим клінічним протоколом медичної допомоги хворим з ЮРА виявлено (табл. 1) зменшення тривалості ранкової скутості $(p<0,05)$, покращення суглобового синдрому, що проявлялося зменшенням артриту кистей ( $<0,05)$, артриту більше трьох суглобів ( $<<0,05)$, симетричного артриту $(p<0,05)$, ентезитів ( $<<0,05)$, болю в хребті $(p<0,05)$, зниженням $(p<0,05)$ ступеня функціональної недостатності суглобів (ФНС). Також при спостереженні за пацієнтами з ЮРА протягом 1 року не відмічено рентгенологічного прогресування захворювання та збільшення потреби в протезуванні суглобів. Також не було виявлено динамічних змін (ні позитивних, ні негативних) системних проявів, наявності увеїту та сакроілеїту.

Таблиця 1. Динаміка клінічних показників у дорослих пацієнтів з ЮРА протягом 1 року спостереження

\begin{tabular}{|c|c|c|c|}
\hline \multirow[b]{2}{*}{ Клінічні прояви } & \multicolumn{2}{|c|}{ Дорослі з ЮРА } & \multirow[b]{2}{*}{$p$} \\
\hline & $\begin{array}{c}\text { на момент першого } \\
\text { огляду }(n=168)\end{array}$ & $\begin{array}{c}\text { через } 1 \text { рік спостере- } \\
\text { ження }(n=56)\end{array}$ & \\
\hline Зріст, м & $1,7 \pm 0,1$ & $1,7 \pm 0,1$ & 0,681 \\
\hline Вага, кг & $62,9 \pm 13,8$ & $60,2 \pm 13,3$ & 0,253 \\
\hline IMT Kг/M² & $21,5 \pm 3,7$ & $20,8 \pm 4,4$ & 0,463 \\
\hline Ранкова скутість, хв & $10(5 ; 30)$ & $2,5(0 ; 11,2)$ & $0,001 *$ \\
\hline Системні прояви & $27(16,1 \%)$ & $9(17,3 \%)$ & 0,846 \\
\hline Артрит >3 суглобів (1 - так, 2 - ні) & $68(40,5 \%)$ & $17(32,7 \%)$ & $0,019 *$ \\
\hline Артрит кистей (1- так, 2 -ні) & $50(29,8 \%)$ & $12(23,1 \%)$ & $0,048^{*}$ \\
\hline Симетричний артрит (1- так, 2 - ні) & $48(28,6 \%)$ & $11(21,2 \%)$ & $0,045^{*}$ \\
\hline Л/в та селезінка (1 - так, 2 - ні) & $12(7,1 \%)$ & $1(1,9 \%)$ & 0,141 \\
\hline Увеїт (1 - так, $2-$ ні) & $22(13,1 \%)$ & $9(17,3 \%)$ & 0,295 \\
\hline Ентероколіт (1 - так, 2 - ні) & $2(1,2 \%)$ & $1(1,9 \%)$ & 0,558 \\
\hline \multicolumn{3}{|l|}{ Наявність артриту: } & \multirow[t]{5}{*}{0,712} \\
\hline олігоартрит & $84(50 \%)$ & $24(46,2 \%)$ & \\
\hline моноартрит & $7(4,2 \%)$ & $1(1,9 \%)$ & \\
\hline поліартрит & $43(25,6 \%)$ & $12(23,1 \%)$ & \\
\hline відсутній артрит & $27(16,1 \%)$ & $8(15,4 \%)$ & \\
\hline Ентезит (1 - так, 2 - ні) & $30(17,9 \%)$ & $4(7,7 \%)$ & $0,001 *$ \\
\hline Дактиліти (1 - так, 2 - ні) & $6(3,6 \%)$ & $1(1,9 \%)$ & 0,474 \\
\hline Сакроілеїт (1 - так, 2 - ні) & $36(21,4 \%)$ & $8(15,4 \%)$ & 0,123 \\
\hline Біль у хребті (1 - так, $2-$ ні) & $77(45,8 \%)$ & $13(25 \%)$ & $0,001 *$ \\
\hline Потреба в протезуванні (1 - так, 2 - ні) & $42(25 \%)$ & $13(25 \%)$ & 0,983 \\
\hline Болючі суглоби (кількість) & $2(0 ; 4)$ & $2(0 ; 2,5)$ & 0,051 \\
\hline Деформовані суглоби, анкілози/протези (кількість) & $0(0 ; 1)$ & $0(0 ; 2)$ & $0,030 *$ \\
\hline Припухлі суглоби (кількість) & $0(0 ; 2)$ & $0(0 ; 1,5)$ & 0,297 \\
\hline Рентгенологічна стадія & $1(0 ; 2)$ & $2(0 ; 3)$ & 0,227 \\
\hline \multicolumn{3}{|l|}{ ФHC } & \multirow[t]{5}{*}{$0,003^{*}$} \\
\hline 0 & 26 & 20 & \\
\hline 1 & 65 & 12 & \\
\hline 2 & 66 & 19 & \\
\hline 3 & 10 & 1 & \\
\hline
\end{tabular}

Примітка. л/в - лімфатичні вузли; ІМТ - індекс маси тіла; ФНС - функціональна недостатність суглобів. 
Огляди літератури, оригінальні дослідження, погляд на проблему, ювілеї

Не дивлячись на зменшення клінічних проявів ЮРА, позитивна динаміка лабораторних показників активності ЮРА в дорослому віці (табл. 2) за DAS28 та JADAS, ШOE, СРБ була відсутня, хоча відмічена тенденція до їх зменшення. Як видно з таблиці 2, у пацієнтів з ЮРА активність захворювання через 1 рік спостереження в дорослому віці зберігається. Однак за візуальною аналоговою шкалою (ВАШ) виявлено покращення стану за оцінкою лікаря ( $p<0,05)$, тоді як за ВАШ пацієнта динаміки не відмічено.

Таблиця 2. Динаміка активності та лабораторних показників у дорослих пацієнтів з ЮРА протягом 1 року спостереження

\begin{tabular}{|l|c|c|c|}
\hline \multicolumn{1}{|c|}{ Показник } & $\begin{array}{c}\text { На момент першого огляду } \\
(n=168)\end{array}$ & $\begin{array}{c}\text { Через } 1 \text { рік спостереження } \\
(n=56)\end{array}$ & p \\
\hline шОЕ, мм/год & $11(5 ; 25,3)[1 ; 70]$ & $10(5 ; 21,5)[2 ; 64]$ & 0,599 \\
\hline DAS28 & $3,2 \pm 1,5$ & $2,7 \pm 1,3$ & 0,141 \\
\hline JADAS & $8(3 ; 13)[0 ; 34]$ & $6(4 ; 10,8)[0 ; 25]$ & 0,431 \\
\hline ВАШ пацієнт, мм & $35(20 ; 50)[0 ; 90]$ & $30(10 ; 45)[0 ; 80]$ & 0,056 \\
\hline ВАШ лікар, мм & $30(10 ; 50)[0 ; 90]$ & $20(10 ; 40)[0 ; 60]$ & $0,045^{*}$ \\
\hline СРБ & $4(4 ; 24)[0 ; 284]$ & $4(2 ; 11)[1 ; 192]$ & 0,265 \\
\hline РФ & $0(0 ; 0)[0 ; 3]$ & $0(0 ; 0)[0 ; 384]$ & $0,007^{*}$ \\
\hline А-ЦЦП & $2(2 ; 2)[1 ; 7,1]$ & $0(0 ; 0)[0 ; 6]$ & $0,000 *$ \\
\hline АНФ & $2(2 ; 2)[1 ; 3]$ & $0(0 ; 0)[0 ; 1]$ & $0,000 *$ \\
\hline ЛПНЩ, ммоль/л & $2,6 \pm 1,1$ & $2,9 \pm 1,3$ & 0,323 \\
\hline Холестерин, ммоль/л & $4,5 \pm 1,1$ & $4,5 \pm 1,1$ & 0,747 \\
\hline Глюкоза, ммоль/л & $4,8 \pm 0,6$ & $4,6 \pm 0,5$ & 0,100 \\
\hline Вітамін 25-(ОН)D, нг/мл & $18,9(14,7 ; 24,4)[6,1 ; 121]$ & $28(22,9 ; 34,6)[12,1 ; 57,9]$ & $0,002 *$ \\
\hline Альбумін, г/л & $39,5(36,2 ; 46)[2,5 ; 50,3]$ & $47,2(46,3 ;)[46,3 ; 48,1]$ & 0,137 \\
\hline Паратгормон, пг/мл & $42,8(24,8 ; 54,5)[1,2 ; 212]$ & $46,6(46,6 ; 46,6)[46,6 ; 46,6]$ & 0,447 \\
\hline Кальцій загальний, ммоль/л & $2,4(2,3 ; 2,4)[1,2 ; 2,9]$ & $2,4(2,3 ; 2,5)[2,3 ; 2,5]$ & 0,680 \\
\hline Кальцій іонізований, ммоль/л & $1,3(1,3 ; 1,3)[1,1 ; 2,4]$ & $1,3(1,3 ;)[1,3 ; 1,3]$ & 0,647 \\
\hline
\end{tabular}

Примітка. А-ЦЦП - антитіла до циклічного цитрулінового пептиду; РФ - ревматоїдний фактор; АНФ - антинуклеарний фактор; лПнщ - ліпопротеїди низької щільності; СРБ - С-реактивний білок; ВАШ - візуальна аналогова шкала; шОЕ - швидкість осідання еритроцитів.

Виявлено зниження антинуклеарного фактора $(p<0,05)$ та антитіл до циклічного цитрулінового пептиду (А-ЦЦП) ( $p<0,05)$, а рівень ревматоїдного фактора (РФ) протягом року спостереження достовірно збільшився $(p<0,05)$, хоча ці лабораторні маркери не корелюють з активністю процесу. Протягом року спостереження за дорослими з ЮРА не виявлено динамічних змін ні в рівні загального холестерину, ні ліпопротеїдів низької щільності (ЛПНЩ) та глюкози.

Крім того, оцінювали біохімічні показники, що пов'язані з мінеральною щільністю кісткової тканини (МЩКТ), такі як рівень загального та іонізованого кальцію, паратгормону, альбуміну та вітаміну 25-(OH) D. За рік спостереження виявлено збільшення рівня вітаміну $25-(\mathrm{OH})(p<0,05)$, хоча він все ще не нормалізувався.

В ході комплексного обстеження дорослих пацієнтів з ЮРА оцінювали стан МЩКТ шляхом рентгенівської денситометрії (табл. 3) та її динаміку протягом року спостереження. В групу контролю ввійшли 84 практично здорових молодих особи відповідних віку та статі.

Таблиця 3. Динаміка мінеральної щільності кісткової тканини у дорослих пацієнтів з ЮРА

\begin{tabular}{|c|c|c|c|c|c|c|}
\hline \multirow[b]{2}{*}{ Показники } & \multirow{2}{*}{$\begin{array}{c}\text { Здорові }{ }^{1} \\
\quad(n=84)\end{array}$} & \multicolumn{2}{|c|}{ Дорослі з ЮРА } & \multirow[b]{2}{*}{$\mathrm{P}^{1-2}$} & \multirow[b]{2}{*}{$\mathrm{P}^{1-3}$} & \multirow[b]{2}{*}{$P^{2-3}$} \\
\hline & & $\begin{array}{l}\text { на момент першо- } \\
\text { го огляду² }(n=168)\end{array}$ & $\begin{array}{c}\text { через } 1 \text { рік спосте- } \\
\text { реження }{ }^{3}(n=56)\end{array}$ & & & \\
\hline 1 & 2 & 3 & 4 & 5 & 6 & 7 \\
\hline 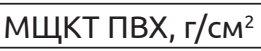 & $1,257(1,168 ; 1,355)$ & $1,042(0,912 ; 1,217)$ & $1,058(0,933 ; 1,256)$ & $0,001 *$ & $0,001 *$ & 0,968 \\
\hline $\begin{array}{l}\text { Т-показник в } \\
\text { ділянці ПВХ }\end{array}$ & $0,49(-0,165 ; 1,19)$ & $-1,02(-1,5 ; 0,723)$ & $-0,8(-1,8 ; 0,9)$ & $0,001 *$ & $0,004^{*}$ & 0,913 \\
\hline $\begin{array}{l}\text { Z-показник в } \\
\text { ділянці ПВХ }\end{array}$ & $0,51(-0,09 ; 0,965)$ & $-0,8(-1,8 ; 0,36)$ & $-0,94(-1,975 ; 0,675)$ & $0,001^{*}$ & $0,001 *$ & 0,701 \\
\hline МЩКТ ШСК г/см² & $1,074(0,999 ; 1,151)$ & $0,937(0,811 ; 1,034)$ & $0,818(0,746 ; 1,049)$ & $0,001 *$ & $0,001 *$ & 0,283 \\
\hline
\end{tabular}


Огляди літератури, оригінальні дослідження, погляд на проблему, ювілеї

Продовження табл. 3

\begin{tabular}{|c|c|c|c|c|c|c|}
\hline 1 & 2 & 3 & 4 & 5 & 6 & 7 \\
\hline $\begin{array}{l}\text { Т-показник в } \\
\text { ділянці ШСК }\end{array}$ & $0,12(-0,375 ; 0,7)$ & $-0,8(-1,6 ;-0,3)$ & $-1,4(-2 ; 0)$ & $0,001 *$ & $0,001 *$ & 0,445 \\
\hline $\begin{array}{l}\text { Z-показник в } \\
\text { ділянці ШСК }\end{array}$ & $0,15(-0,355 ; 0,79)$ & $-0,6(-1,323 ; 0,175)$ & $-0,9(-1,8 ; 0,2)$ & $0,001 *$ & $0,001 *$ & 0,482 \\
\hline $\begin{array}{l}\text { МЩКТ трохантер, } \\
\text { г/см² }\end{array}$ & $0,879(0,81 ; 0,959)$ & $0,809(0,666 ; 0,902)$ & $0,633(0,575 ; 0,954)$ & $0,001 *$ & $0,003 *$ & $0,042 *$ \\
\hline $\begin{array}{l}\text { Т-показник в } \\
\text { ділянці трохантер }\end{array}$ & $-0,09(-0,495 ; 0,455)$ & $-0,35(-1,825 ; 0,178)$ & $-1,9(-2 ; 0,575)$ & $0,013^{*}$ & $0,013 *$ & 0,299 \\
\hline $\begin{array}{l}\text { Z-показник в } \\
\text { ділянці трохантер }\end{array}$ & $-0,11(-0,55 ; 0,46)$ & $-0,3(-1,495 ; 0,17)$ & $-1,55(-1,9 ; 0,475)$ & $0,014^{*}$ & $0,019 *$ & 0,328 \\
\hline 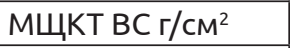 & $1,071(1,016 ; 1,172)$ & $1,031(0,879 ; 1,124)$ & $0,82(0,746 ; 1,113)$ & $0,002 *$ & $0,003 *$ & 0,298 \\
\hline $\begin{array}{l}\text { Т-показник в } \\
\text { ділянці ВС }\end{array}$ & $0,325(-0,23 ; 0,86)$ & $-0,4(-1,54 ; 0,3)$ & $-1,5(-2,05 ; 0,55)$ & $0,001 *$ & $0,011 *$ & 0,334 \\
\hline $\begin{array}{l}\text { Z-показник в } \\
\text { ділянці ВС }\end{array}$ & $0,365(-0,183 ; 0,893)$ & $-0,45(-1,213 ; 0,323)$ & $-1,25(-1,925 ; 0,425)$ & $0,001 *$ & $0,001 *$ & 0,170 \\
\hline 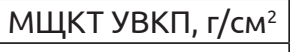 & $0,41(0,349 ; 0,482)$ & $0,409(0,325 ; 0,446)$ & $0,375(0,263 ; 0,566)$ & 0,353 & 0,431 & 0,798 \\
\hline $\begin{array}{l}\text { Т-показник в } \\
\text { ділянці УВКП }\end{array}$ & $0,1(-0,85 ; 1,17)$ & $-1,7(-3,55 ;-0,1)$ & $-1,6(-3,3 ;-0,1)$ & $0,001 *$ & $0,001 *$ & 0,713 \\
\hline $\begin{array}{l}\text { Z-показник в } \\
\text { ділянці УВКП }\end{array}$ & $0,1(-0,85 ; 1,17)$ & $-1,55(-3 ;-0,525)$ & $-1,6(-3,3 ;-0,1)$ & $0,001 *$ & $0,001 *$ & 0,805 \\
\hline
\end{tabular}

Примітка. ЮРА - ювенільний ревматоїдний артрит; МЩКТ - мінеральна щільність кісткової тканини, ПВХ - поперековий відділ хребта, ШСК - шийка стегнової кістки, ВС - весь скелет, УВКП - ультрадистальний відділ кісток передпліччя.

Встановлено, що як на момент первинного огляду, так і після спостереження протягом 1 року МЩКТ в різних ділянках скелета та Z-і Т-показники відповідних ділянок були достовірно нижчими, ніж у групі контролю. Однак, при оцінці МЩКТ у різних відділах скелета та Z-і Т-показників відповідних ділянок не виявлено їх динамічних змін протягом року спостереження за пацієнтами з ЮРА.

Оскільки ВООЗ розширила визначення здоров'я як «стан фізичного, психічного та соціального благополуччя, а не тільки відсутність хвороб", цікавим $\epsilon$ дослідження ЯЖ у дорослих пацієнтів $з$ ЮРА. Термін "якість життя» (ЯЖ) відображає рівень благополуччя людини та характеризує різноманітні умови життя, ступінь задоволення потреб людини. Традиційно зміни, що виникають у хворої людини, а також ефективність лікування та реабілітації лікар оцінює на підставі динаміки скарг, об'єктивних даних, параклінічних показників. Використання показника ЯЖ, що пов'язана зі здоров'ям, дозволяє узагальнено оцінити ступінь адаптації людини до хвороби та можливість виконання звичних функцій, що відповідають ії соціально-економічному стану, тобто визначити, наскільки хвороба не дозволяє людині жити так, як вона 6 хотіла. Тому наша увага була звернена на оцінку Яж за SF-36, рівнів алекситимії та депресії. Однак через 1 рік спостереження (табл. 4) за дорослими пацієнтами з ЮРА не виявлено відмінностей ні за ЯЖ та ії шкалами, ні за рівнем алекситимії, ні за ступенем депресії. Хоча 45 \% пацієнтів з ЮРА після 1 року спостереження в дорослому віці мали від легкої, субклінічної, до середньої тяжкості депресію, тоді як на момент первинного огляду дорослим ревматологом ознаки депресії різного ступеня спостерігали у 61,1 \% пацієнтів.

Таблиця 4. Динаміка показників якості життя, алекситимії та депресії у дорослих пацієнтів з ЮРА

\begin{tabular}{|c|c|c|c|}
\hline \multirow[b]{2}{*}{ Показники } & \multicolumn{2}{|c|}{ Дорослі з ЮРА } & \multirow[b]{2}{*}{$\mathrm{p}$} \\
\hline & $\begin{array}{l}\text { на момент першого огляду } \\
(n=168)\end{array}$ & $\begin{array}{c}\text { через } 1 \text { рік спостереження } \\
(n=56)\end{array}$ & \\
\hline 1 & 2 & 3 & 4 \\
\hline ЯЖ за SF-36 PCS & $44,7 \pm 9,9(17,2 ; 64,8)$ & $47,3 \pm 10,5(21,4 ; 65)$ & 0,226 \\
\hline Яж за SF-36 MCS & $45,5 \pm 11,1(18,4 ; 66,4)$ & $44,2 \pm 13,8(13,7 ; 68)$ & 0,847 \\
\hline PF & $70,5 \pm 25,3(0 ; 100)$ & $71,9 \pm 22,8(20 ; 100)$ & 0,996 \\
\hline RF & $60 \pm 33(0 ; 100)$ & $65,4 \pm 30,2(0 ; 100)$ & 0,539 \\
\hline $\mathrm{BP}$ & $55,3 \pm 26,5(0 ; 100)$ & $60,2 \pm 24,3(22 ; 100)$ & 0,470 \\
\hline $\mathrm{GH}$ & $51,6 \pm 22,5(5 ; 100)$ & $49,4 \pm 23,2(0 ; 100)$ & 0,741 \\
\hline
\end{tabular}




\begin{tabular}{|l|c|c|c|}
\hline \multicolumn{1}{|c|}{1} & 2 & 3 & 4 \\
\hline $\mathrm{VT}$ & $54,6 \pm 21,1(6,3 ; 100)$ & $49,7 \pm 24,8(6,3 ; 93,8)$ & 0,381 \\
\hline $\mathrm{SF}$ & $71,5 \pm 23,9(0 ; 100)$ & $71,4 \pm 26,2(12,5 ; 100)$ & 0,951 \\
\hline $\mathrm{RE}$ & $66,2 \pm 33,4(0 ; 100)$ & $66,3 \pm 29,6(0 ; 100)$ & 0,735 \\
\hline MH & $65,7 \pm 20(10 ; 100)$ & $60,2 \pm 21,4(20 ; 95)$ & 0,281 \\
\hline Алекситимія & $66,4 \pm 11,2(41 ; 90)$ & $65,3 \pm 10,9(44 ; 79)$ & 0,837 \\
\hline PHQ-9 & $6(2 ; 11)$ & $4(4 ; 7,8)$ & 0,274 \\
\hline
\end{tabular}

Примітка. PCS - фізичне благополуччя, MCS - психологічне благополуччя; PF - фізичне функціонування; RF - рольове функціонування; ВP - інтенсивність болю; GH - загальний стан здоров'я, VT - життєва активність, SF - соціальне функціонування, $\mathrm{RE}$ - рольові емоції, МН - психічне здоров'я; $\mathrm{P}_{1}$ - порівняння груп здорових та пацієнтів з ЮРА; PHQ-9 - опитувальник пацієнта про стан здоров'я (Patient Health Questionnaire - PHQ-9) - шкала самооцінки депресії з дев'яти пунктів.

Виявивши стабілізацію як клінічного та лабораторного, так і психологічного стану, а також якості життя дорослих пацієнтів з ЮРА, ми провели аналіз терапії наших пацієнтів. Встановлено, що пацієнти з ЮРА отримували протягом всієї історії захворювання послідовно або паралельно такі хворобомодифікуючі препарати: метотрексат - 98 (58,3 \%) пацієнтів; амінохінолінові препарати - 53 (31,5 \%) пацієнти, сульфосалазин - 45 (26,8 \%) паці$\epsilon$ нтів, лефлунамід - $12(7,1 \%)$ пацієнтів, ендоксан 8 (4,8 \%) пацієнтів, азатіоприн - 4 (2,4 \%) пацієнти, лейкеран - 2 (1,2\%) пацієнти, препарати золота - 2 $(1,2 \%)$ пацієнти. Імунобіологічну терапію отримували 25,5 \% пацієнтів - найчастіше призначали інгібітори фактора некрозу пухлин-альфа - 35 (20,8 \%) пацієнтів (з них, адалімума6 - 29 пацієнтів, етанерцепт - 4 пацієнти, голімумаб - 2 пацієнти), тоцилізума6 - 6 пацієнтів, ритуксимаб - 2 пацієнти. Встановлено, що 32 (19\%) пацієнти від дебюту захворювання до дорослого віку взагалі не приймали хворобомодифікуючих препаратів та отримували терапію лише нестероїдними протизапальними засобами та локально глюкокортикоїдами, 53 (31,5 \%) пацієнти приймали протягом всієї тривалості за- хворювання 1 хворобомодифікуючий препарат, $34(20,2 \%)$ пацієнти отримували послідовно або паралельно 2 хворобомодифікуючих препарати, 11 (6,5 \%) пацієнтів отримували послідовно або паралельно 3 хворобомодифікуючих препарати, 19 $(11,3 \%)$ пацієнтів отримували 1 хворобомодифікуючий препарат та 1 препарат ІБТ, 10 (6\%) пацієнтів отримували 2 хворобомодифікуючих препарати та 1 препарат ІБТ, 9 (5,4 \%) пацієнтів отримувало більше 3 хворобомодифікуючих препаратів або більше 2 препаратів ІБТ. Після корекції терапії та спостереження за пацієнтами протягом 1 року встановлено (табл. 5), що достовірно зменшилася потреба в інтенсифікації терапії в т.ч. ІБТ $(p<0,05)$, збільшилась кількість пацієнтів, що приймає ІБТ, зменшилась кількість пацієнтів, що приймає ГК, та відповідно, зменшилась середня доза ГК $(p<0,05)$.

Наші дослідження збігаються з результатами [7], де автори показали, що активність ЮРА і відвідуваність медичних закладів залишалися стабільними протягом перехідного періоду. Однак, в цьому дослідженні частка пацієнтів з ЮРА у перехідний період на ІБТ була високою, а активність захворювання була в цей період низькою. Автори

Таблиця 5. Динаміка медикаментозної терапії дорослих пацієнтів з ювенільним ревматоїдним артритом

\begin{tabular}{|c|c|c|c|}
\hline \multirow[b]{2}{*}{ Показники } & \multicolumn{2}{|c|}{ Дорослі з ЮРА } & \multirow[b]{2}{*}{$\mathrm{p}$} \\
\hline & $\begin{array}{c}\text { на момент першого огляду } \\
(n=168)\end{array}$ & $\begin{array}{c}\text { через } 1 \text { рік спостереження } \\
(n=56)\end{array}$ & \\
\hline Потреба в інтенсифікації терапії ( \%) & $79(47 \%)$ & $8(15,4 \%)$ & $0,001 *$ \\
\hline \multicolumn{3}{|l|}{ Якщо так, то чим: } & \multirow{4}{*}{0,001 * } \\
\hline IБT & $42(25 \%)$ & $7(13,5 \%)$ & \\
\hline Інші ХМПРП & $34(20,2 \%)$ & $4(7,7 \%)$ & \\
\hline Комбіновані ХМПРП & $5(3 \%)$ & $0(0 \%)$ & \\
\hline \multicolumn{3}{|l|}{ IET } & \multirow{4}{*}{0,597} \\
\hline Зараз $\epsilon$ & $23(13,7 \%)$ & $9(16,1 \%)$ & \\
\hline Була раніше & $12(7,1 \%)$ & $2(3,6 \%)$ & \\
\hline Немає & $133(79,2 \%)$ & $45(80,4 \%)$ & \\
\hline Прийом ГК & $2(1 ; 2)[1 ; 2]$ & $0(0 ; 3)[0 ; 36]$ & $0,000^{*}$ \\
\hline Середня доза ГК, мг & $4(2,5 ; 8)[0 ; 28]$ & $0(0 ; 4)[0 ; 36]$ & $0,001^{*}$ \\
\hline
\end{tabular}

Примітка. ГК - глюкокортикоїди; ІБТ - імунобіологічна терапія; ХМПРП - хворобомодифікуючі протиревматичні препарати. 
Огляди літератури, оригінальні дослідження, погляд на проблему, ювілеї

дослідження [7] показали, що частка пацієнтів з ІБТ була вищою (48 \%), ніж у нашій роботі (25,5\%), що пояснює нижчу активність захворювання. Хоча результати нашої роботи відповідають іншому недавньому дослідженню, проведеному в Тампере, Фінляндія, де 29 \% дорослих, хворих на ЮРА, підлітків і молодих були на ІБТ і 58 \% пацієнтів мали різний ступінь активності захворювання протягом попереднього року [8]. Високі показники відвідуваності медичних закладів та ремісії і низька активність захворювання, а також хороший функціональний статус можуть бути досягнуті лише шляхом суворого контролю хвороби, вироблення стратегії лікування, яка $\epsilon$ привабливою та зрозумілою для пацієнтів, та покращеними стосунками між лікарем та пацієнтом в період переходу пацієнтів з ЮРА до дорослої ревматологічної служби. Перспективні дослідження, як і раніше, необхідні, щоб оцінити довгострокові впливи лікування ІБТ на ЮРА в дорослому віці. Наше дослідження підкреслює, що для лікування підлітків та молодих людей необхідне призначення ІБТ для контролю захворювання. 3 метою покращенння ведення та досягнення оптимальних результатів лікування молодих пацієнтів з ЮРА в перехідний період та в подальшому в дорослій ревматологічній службі необхідні спеціальні знання та навички спілкування.

Наше дослідження має певні обмеження. Спостереження за пацієнтами проводилося протягом 1 року, що не дає можливості оцінити довготривалий вплив ЮРА на загальний стан пацієнта в дорослому віці. Також ми не оцінювали клінічні прояви, стан МЩКТ та Яж залежно від проведеного лікування та ILAR-варіанту ЮРА.

Наше дослідження також має сильні сторони.

1. Група хворих складалася з пацієнтів з ЮРА, що відповідали чітким критеріям ILAR в перехідний період.

2. Це перше дослідження в Україні, яке включало імунобіологічну терапію як потенційний фактор, що впливає на МЩКТ та ЯЖ дорослих пацієнтів з ЮРА.

Висновки. 1. У дорослих пацієнтів з ЮРА, що перебували під спостереженням протягом 1 року, відмічається стабілізація як клінічного, так і психологічного стану.

2. При спостереженні за дорослими пацієнтами з ЮРА протягом 1 року на фоні терапії згідно з уніфікованим клінічним протоколом медичної допомоги пацієнтам з ЮРА виявлено зменшення тривалості ранкової скутості та покращення суглобового синдрому, що відобразилося в зниженні ступеня функціональної недостатності суглобів та припиненні рентгенологічного прогресування, хоча лабораторна активність утримувалася.

3. При оцінці МЩКТ у різних відділах скелета та Z- і Т-показників відповідних ділянок не виявлено їх динамічних змін протягом року спостереження за дорослими пацієнтами з ЮРА.

4. Через 1 рік спостереження за дорослими пацієнтами з ЮРА не виявлено відмінностей за ЯЖ та ії̈ шкалами, алекситимії та ступеня депресії, що свідчить про необхідність корекції за участі відповідних спеціалістів.

5. Встановлено, що 32 (19\%) пацієнти від дебюту захворювання до дорослого віку не приймали хворобомодифікуючих препаратів та отримували терапію лише нестероїдними протизапальними засобами та локально глюкокортикоїдами, 53 (31,5 \%) пацієнти приймали протягом всієї тривалості захворювання 1 хворобомодифікуючий препарат, 34 (20,2 \%) пацієнти отримували послідовно або паралельно 2 хворобомодифікуючих препарати, 11 (6,5 \%) пацієнтів отримували послідовно або паралельно 3 хворобомодифікуючих препарати, 19 (11,3 \%) пацієнтів отримували 1 хворобомодифікуючий препарат та 1 препарат ІБТ, 10 (6 \%) пацієнтів отримували 2 хворобомодифікуючих препарати та 1 препарат ІБТ, 9 (5,4 \%) пацієнтів отримували більше 3 хворобомодифікуючих препаратів або більше 2 препаратів ІБТ.

\section{ЛІТЕРАТУРА}

1. Спадкоємність та ефективність терапії ювенільного ідіопатичного артриту: напрямки персоніфікованої терапії / В. М. Коваленко, Л. І. Омельченко, О. Б. Яременко [та ін.] // Укр. Ревм. журнал. - 2016. - № 64 (2). C. 9-16.

2. Стасенко Т. Чи зможуть продовжити лікування ювенільного ревматоїдного артриту дорослі пацієнти? / Т. Стасенко //Укр. Мед. Часопис. - Режим доступу: https:// www.umj.com.ua/article/121020/chi-zmozhut-prodovzhitilikuvannya-yuvenilnogo-revmatoyidnogo-artritu-doroslipatsiyenti

3. Petty R. E. International League of Associations for Rheumatology classification of juvenile idiopathic arthritis:

second revision, Edmonton / R. E. Petty, T. R. Southwood, P. Manners // 2001. - J. Rheumatol. - 2004. - Vol. 31. P. 390-392.

4. Assessment of the SF-36 version 2 in the United Kingdom / C. Jenkinson, S. Stewart-Brown, S. Petersen, C. Paice // J. Epidemiol. Community Health. - 1999. - Vol. 53 (1). P. 46-50.

5. Campolina A. G. SF-36 and the development of new assessment tools for quality of life / A. G. Campolina, R. M. Ciconelli // Acta Reumatol. Port. - 2008. - Vol. 33 (2). P. 127-133.

6. Міністерство охорони здоров'я України (2012) Наказ МОЗ України від 22.10.2012 р. № 832 «Про затвер- 
Огляди літератури, оригінальні дослідження, погляд на проблему, ювілеї

дження Уніфікованого клінічного протоколу медичної допомоги дітям, хворим на ювенільний артрит», Київ.

7. Relas H. Outcome of transition phase patients with juvenile idiopathic arthritis / H. Relas, R. Luosujarvi, S. Kosola // Modern Rheumatology. - 2017. https://doi.org/10. $1080 / 14397595.2017 .1416890$

\section{REFERENCES}

1. Kovalenko, V.M., Omelchenko, L.I., Yaremenko, O.B., Marushko, T.V., Bohmat, L.F., Harmish, O.O., ... Dzhus, M.B. (2016). Spadkoiemnist ta efektyvnist terapii yuvenilnoho idiopatychnoho artrytu: napriamky personifikovanoi terapii [Continuity and effectiveness of juvenile idiopathic arthritis therapy: the direction of personified therapy]. Ukr. Revm. Zhurnal - Ukrainian Rheumatological Journal, 64 (2), 9-16 [in Ukrainian].

2. Stasenko, T. (2018). Chy zmozhut prodovzhyty likuvannia yuvenilnoho revmatoidnoho artrytu dorosli patsiienty? [Will adult patients continue to treat juvenile rheumatoid arthritis?]. Ukr. Med. Chasopys - Ukrainian Medical Journal. Retrieved from: https://www.umj.com.ua/article/121020/ chi-zmozhut-prodovzhiti-likuvannya-yuvenilnogo-revmatoyidnogo-artritu-dorosli-patsiyenti [in Ukrainian].

3. Petty, R.E., Southwood, T.R. \& Manners, P. (2004). International League of Associations for Rheumatology classification of juvenile idiopathic arthritis: second revision, Edmonton 2001. J. Rheumatol., 31, 390-392.

4. Jenkinson, C., Stewart-Brown, S., Petersen, S. \& Paice, C. (1999). Assessment of the SF-36 version 2 in the United Kingdom. J. Epidemiol. Community Health, 53 (1), 46-50.
8. Disease activity of idiopathic juvenile arthritis continues through adolescence despite the use of biologic therapies / K. L. Vidqvist, M. Malin, T. Varjolahti-Lehtinen, M. M. Korpela // Rheumatology. - 2013. - Vol. 52. P. 1999-2003.

\section{ДИНАМИЧЕСКОЕ НАБЛЮДЕНИЕ ЗА ВЗРОСЛЫМИ ПАЦИЕНТАМИ С ЮВЕНИЛЬНЫМ РЕВМАТОИДНЫМ АРТРИТОМ}

\section{Национальный медицинский университет имени А. А. Богомольца}

๑М. Б. Джус

РЕзЮМЕ. В течение последних лет в лечении ЮРА произошел существенный прогресс, связанный с разработкой инновационных лекарственных средств, хотя их доступность для украинских пациентов ограничена из-за высокой цены и отсутствия достаточного государственного обеспечения.

Цель работы - провести обследование молодых взрослых пациентов с ЮРА на момент обращения к взрослому ревматологу и через год наблюдения с оценкой динамики клинических, лабораторных показателей, психологического состояния, состояния минеральной плотности костной ткани и проведенного лечения.

Материал и методы. В исследование включены 168 пациентов с ЮРА, достигших 18-летнего возраста, обследованных на базе Александровской городской клинической больницы, г. Киев, Украина. Оценивали клиниколабораторные показатели активности заболевания, качество жизни (KЖ) по SF36, алекситимию по TAS-10, уровень депрессии PHQ-9, состояние минеральной плотности костной ткани и лечение.

Результаты. При динамическом наблюдении за взрослыми пациентами с ЮРА в течение 1 года на фоне терапии согласно унифицированному клиническому протоколу медицинской помощи больным с ЮРА выявлено уменьшение продолжительности утренней скованности ( $<0,05)$, улучшение суставного синдрома, уменьшение артрита кистей $(p<0,05)$, артрита более трех суставов ( $<<0,05)$, симметричного артрита $(p<0,05)$, энтезитов $(p<0,05)$, боли в позвоночнике ( $<<0,05)$, что отразилось в снижении $(p<0,05)$ степени функциональной недостаточности суставов и отсутствии рентгенологического прогрессирования, хотя не обнаружено динамических изменений со стороны системных проявлений, наличия увеита и сакроилеита. Выявлено отсутствие положительной динамики лабораторных показателей активности ЮРА во взрослом возрасте за DAS28 и JADAS, COЭ, СРБ, хотя имеется тенденция к их уменьшению. У пациентов с ЮРА заболевание остается активным через 1 год наблюдения во взрослом возрасте. За год наблюдения выявлено увеличение уровня витамина Д 25-(OH) (p<0,05), хотя он все еще не нормализовался. Установлено, что как на момент первичного осмотра, так и после наблюдения в течение 1 года МПКТ в различных участках скелета, Z- и Т-показатели соответствующих участков были достоверно ниже, по сравнению с группой контроля. Однако при оценке МПКТ в различных отделах скелета, Z- и Т-показателей соответ- 
Огляди літератури, оригінальні дослідження, погляд на проблему, ювілеї

ствующих участков динамических изменений в течение года наблюдения не выявлено. Через 1 год наблюдения не выявлено различий ни по КЖ и ее шкалам, ни по уровню алекситимии, ни по степени депрессии. Хотя 45 \% пациентов с ЮРА после 1 года наблюдения во взрослом возрасте имели от легкой "субклинической" к средней тяжести депрессии, тогда как на момент первичного осмотра взрослым ревматолого

Выводы. У пациентов с ЮРА на этапе переходной медицины, находившихся под наблюдением в течение 1 года, отмечается стабилизация как клинического, так и психологического состояния. Через 1 год наблюдения выявлено уменьшение продолжительности утренней скованности и улучшение суставного синдрома, что отразилось в снижении степени функциональной недостаточности суставов и прекращении рентгенологического прогрессирования, хотя лабораторная активность удерживалась высокой. При оценке МПКТ в различных отделах скелета, Z- и Т-показателей соответствующих участков, положительных динамических изменений в течение года наблюдения не выявлено. Через 1 год наблюдения за взрослыми пациентами с ЮРА не обнаружено различий в КЖ и по ее шкалам, алекситимии и степени депрессии, что свидетельствует о необходимости коррекции сучастием соответствующих специалистов. Установлено, что 32 (19\%) пациента от дебюта заболевания до взрослого возраста не принимали болезньмодифицирующих препаратов (БМПРП), и использовали только терапию НПВП и локальными ГК, 53 (31,5 \%) пациента принимали на протяжении всей продолжительности заболевания 1 БМПРП, 34 (20,2 \%) пациента получали последовательно или параллельно 2 БМПРП, 11 (6,5 \%) пациентов получали последовательно или параллельно 3 БМПРП, 19 (11,3 \%) пациентов получали 1 БМПРП и 1 препарат иммунобиологической терапии (ИБТ), 10 (6 \% ) пациентов получали 2 БМПРП и 1 препарат ИБТ, 9 (5,4%) пациентов получали более 3 БМПРП или более 2 препаратов ИБТ.

КЛЮЧЕВЫЕ СЛОВА: ювенильный ревматоидный артрит (ЮРА); взрослый возраст; качество жизни; МПКТ; лечение.

\section{DYNAMIC MONITORING OF ADULT PATIENTS WITH JUVENILE IDIOPATHIC ARTHRITIS}

@M. B. Dzhus

\section{O. Bohomolets National Medical University}

SUMMARY. During the last years, significant progress has been made in the treatment of juvenile idiopathic arthritis (JIA), although the availability of modern treatment is limited for Ukrainian patients due to high costs and lack of adequate government support.

The aim of the work - to conduct an examination of young adult patients with JIA at the time of referral to an adult rheumatologist and one year follow-up with an assessment of the dynamics of clinical signs, laboratory data, psychological state, bone mineral density (BMD) and treatment.

Materials and Methods: The study included 168 patients with JIA, > 18 years old. All patients were examined on the basis of Oleksandrivska Town Clinical Hospital, Kyiv, Ukraine. Clinical and laboratory data of disease activity, quality of life (QoL) by SF36, alexethymia by TAS-10, level of depression of PHQ-9, bone mineral density and treatment were evaluated.

Results. During the 1 year follow-up of adult patients with JIA on the basis of the treatment according to the unified clinical protocol of medical care, the patients with JIR showed a decrease in the duration of morning stiffness ( $p<0.05$ ), improvement of articular syndrome, reduction of arthritis of the hands $(p<0.05)$, arthritis of $>3$ joints $(p<0.05)$, symmetrical arthritis $(p<0.05)$, enthezites $(p<0.05)$, spinal pain $(p<0.05)$, that reflected in a decrease $(p<0,05)$ of the degree of functional dissability of the joints and the absence of X-rays progression. Although no dynamic changes of systemic manifestations, uveitis and sacroilitis were detected. There was no positive dynamics of DAS28 and JADAS, ESR, CRP. Patients with JIA have active disease after 1 year of observation in adulthood. An increase in the vitamin D 25- $(\mathrm{OH})$ level $(p<0.05)$ was detected in one year of follow-up, although it was still not normalized. It was established that both at the time of the primary examination and after 1 year follow-up the BMD in different parts of the skeleton, the Z- and T-score were reliably lower than in the control group. However, when evaluating the BMDs in different parts of the skeleton, Z-and T-score no dynamic changes were observed during the year of observation. After 1 year follow-up no differences were detected either on QoL and its scales, nor on the level of alexethymia, nor on the degree of depression. Although $45 \%$ of patients with JIA after 1 year of follow-up in adulthood had a mild "subclinical" to moderate severity of depression, while at the time of primary examination by adult rheumatologist, $61.1 \%$ of patients experienced varying degrees of depression.

Conclusions. Patients with JIA durring transition period after 1 year follow-up showed stabilization of both clinical and psychological states. After 1 year of observation, a decrease in the duration of morning stiffness and improvement of articular syndrome was revealed, that is reflected in a decrease in the degree of functional dissability of the joints and the X-ray progression, although laboratory activity is maintained high. During the evaluation of the BMDs in different parts of the skeleton, Z- and T-scores, no positive dynamic changes were observed during the year of observation. After 1 year follow-up of adult patients with JIA, no differences in QoL and its scales, alexethymia, and degree of depression were found, indicating the need for their correction with the participation of appropriate specialists. 32 (19\%) patients durring JIA course did not receive any disease-modifying drugs (DMDs), 53 (31.5\%) patients received 1 DMD durring JIA course, 34 (20.2\%) patients were received sequentially or concurrently 2 DMDs, 11 (6.5\%) patients received sequentially or concurrently 3 DMDs, 19 (11.3\%) patients received 1 DMD and 1 immunobiologic therapy (IBT), 10 (6 \%) patients received 2 DMDs and 1 IBT, 9 (5.4\%) patients - more than 3 DMARDs or more and 2 IBT.

KEY WORDS: juvenile idiopathic arthritis; adults; quality of life; BMD; treatment. 